Retraction Notice

\title{
RETRACTED: Decision support system in Predicting the Best teacher with Multi Atribute Decesion Making Weighted Product (MADMWP) Method
}

\author{
Solikhun ${ }^{1}$, Agus Perdana Windarto ${ }^{2}$, Amri $^{3}$
}

${ }^{1}$ AMIK \&STIKOM Tunas Bangsa, Street Jendral Sudirman Blok No. 1-3, Pematangsiantar 21127

Sumatera Utara, Indonesia

Following a rigorous, carefully concerns and considered review of the article published in International Journal of Artificial Intelligence Research to article entitled "Decision support system in Predicting the Best teacher with Multi Atribute Decesion Making Weighted Product (MADMWP) Method" Vol 1, No 1, pp. 47-53, juny 2017, DOI: https://doi.org/10.29099/ijair.v1i1.1

This paper has been found to be in violation of the International Journal of Artificial Intelligence Research Publication principles and has been retracted.

The article contained redundant material, the editor investigated and found that the paper published in JURASIK(Jurnal Riset Sistem Informasi dan Teknik Informatika) Vol. 1, No. 1, pp. 56-63, 2016, http://ejurnal.tunasbangsa.ac.id/index.php/jurasik/article/view/9 The document and its content has been removed from International Journal of Artificial Intelligence Research, and reasonable effort should be made to remove all references to this article. 